\title{
IMPROVING STUDENTS' WRITING SKILL USING GRAMMALY APPLICATION FOR SECOND GRADE IN SENIOR HIGH SCHOOL
}

\author{
Sri Fahmi ${ }^{1}$, Cynantia Rachmijati ${ }^{2}$ \\ IKIP Siliwangi \\ ${ }^{1}$ srifahmi44@ student.ikipsiliwangi.ac.id, ${ }^{2}$ cynantia@yandex.com
}

\begin{abstract}
Writing is the most important skill in learning a language. Through writing is a way to express student's ideas, but most students are still deeply mistaken in spelling, grammar, vocabulary and also punctuation. The one way to fix it is to give the students solution with a tool that can help and guide to show their mistake. This research aim of improving students writing skills using Grammarly application. By using Grammarly students are guided to find out students' errors and how to fix it and improve their writing skills using Grammarly application, especially in second grade in senior high school. This research used a qualitative method through pre-test and posttest. The subject of this research is consists of 32 students in second grade in senior high school. The research finding that's after using Grammarly application can improve student's ability in writing and express what their thought and felt. It suggested that students should be confident in conveying their ideas into written form as well as maximizing this Grammarly application to help them find errors in writing and can find the correct one. It is recommended that teachers give more serious attention errors of students in writing because of solving.
\end{abstract}

Keywords: Writing Skill, Grammarly Application

\section{INTRODUCTION}

In process of English teaching and learning process there are four skills that must be mastered by the learner, there are listening, speaking, reading and writing. Writing is one of the skills that requires your full attention. Writing is one of difficult skill must be mastered. Base on Richard and Renandya (2002:303) state in Ratnaningsih(Gardner, 2016), that writing is the most difficult skill for second or foreign language learner to master. Some students can speak English fluency and confidently, although they have diffulties in conveying their writing skills. But if you can mastered in writing you will be easy mastered the other skills.

Based on Cahyono and Widiati (2011) state in Almirawti (Inez E.A \& C. Nur, 2018), that's writing is a complex skill in learning language process than other skills (listening, reading and speaking). Graham (2006) as cited in Parmawati, Santoso, \& Yana (2020) states that students have to struggle significantly with writing and if someone does not write well he will find difficulties in the process of learning, education, andwork. However writing is important skill because writing is the way to share and deliver our idea in our brain into writing language and writing also is tool of communication indirectly to express what is thought and felt. Writing is producing a written text by the writer which used to deliver the information to the reader, Warigan and Doyin (2005) as cited in Ruhama (Ruhama \& Purwaningsih, 2019) argued that's language skill which used for communicating indirectly is writing. Writing is ability to communicate ideas, opinion, and feeling in writing. It can be concluded that writing is process of complex thing to produce or express and deliver our idea, thinking and feeling through written texts. 
Nunan (1989:36) as cited in Risky (Tambusai, 2018) also states that component of writing include control of content, format, spelling, grammar, vocabulary and punctuation. Writing needed ability to choose good word with right grammar. Through four that component is one of the ways to improve students' writing skills. In statements above the writing is ability to producing component of writing to deliver massage from the writer to the reader. Based on that statement, written text provide clear and almost complete explanation which include of the component of writing, because to express to written text requires careful thought and the put into a word, sentences, paragraphs, and then form a written text.

According to Johns in Yi (2009) state in (Iftanti, 2016), that's there are several purpose of writing first is to express the writers feeling and thinking, second to entertain the reader, than to inform to reader what the writer purpose, and to persuade the reader. Based on Nation (2009:119) in Kareviati, Yugafiati and Rasmini (Siliwangi, n.d.2020) argue that in writing students has difficulties to deliver their idea into written form. Some students are not confident and lazy to write and also have to considere to understand about vocabulary, diction, punctuation, and last grammar which is the most important thing in writing.

Writing has an important thing and interrelated to produce the written text, but students usually find difficulties to develop their own written text. Based on Megaiab (2014:190) as cited Ni (Mustafa et al., 2016), revealed that students has producing many errors in their written text there are include in composition, grammatical found in spelling, plural, verb, tenses, preposition, articles, capitalization and punctuation.

According to Bryne (1988) state in (Pratiwi, 2015), there are some difficulties students have in writing, there are:

1. The students are weak of vocabulary mastery so they are difficult to express their idea into the word.

2. The students are weak of grammar mastery so they are difficult to write grammatical sentence.

3. The students are weak of spelling and punctuation so they are not able write properly and correctly.

4. The students are lack of motivation in learning writing so they are not confidence performing in writing.

According to Brown (2007:262),Corder (1991:36-37) and Ellis (1997:18) stated in (Mustafa et al., 2016) they assumed that's there are four categories which they are classification of students error in writing. There are:

1. Omission is the error which do by the students because they are cannot produce the correct word. This errors can found in grammatical morphemes such as verb, articles, nouns, preposition, inflection, are left out more often than the content of morphemes which brings the meaning.

2. Addition is the mistake which add some needless and fired part of words. Using both modal and verb be or adding -s to noun which are similar in form for both singular and plural form, or uncountable noun.

3. Selection is the error which do by students when they are choosing the wrong word form, or can be mentioned misformation or malformations. This mistaken usually include of phoneme, morpheme, structure or vocabulary items.

4. Misordering is error which do by the students in an incorrect order of word in a sentences. Usually students use Indonesian transferring or translating from Bahasa Indonesia. 
According to statements above the one of the ways to improve students' writing skills is to free students to explore and explain and also express their idea with their own word, but students have difficulty finding the right and correct words to use, even many do not match the correct grammar and spelling. Those difficulties and weaknesses make students unable to improve their writing skills, students does not know their mistakes when they are writing. What most do to solve the problems? To solve this problems, we can use Grammarly to help find out the correct one.

Grammarly was founded in 2008 by Alex Sheychenko and Max Lytvyn which the head office is in the USA. Whatever you are, grammarly provide the system to find out the correct one. No need to be like the condition of your writing, Grammarly adjusts to your needs, and gives us confidence in writing English. Grammarly is an application that can help in learning English especially writing, that's can called Grammarly is writing assistant, that mean this application prof read and edit their documents for grammar and spelling. Grammarly checks types of spelling, grammar and punctuation errors, and enhances vocabulary usage.

Base on Grammarly application, Grammarly can give advice and guide very helpful feedback on writing. Passive voice can be fixed by Grammarly, and it can handle classical word-choice mistakes. It can also help with inconsistencies such as switching between e-mail and email. It can even help when you wanna refine or slang or formality level. That's especially useful when writing for a broad audience ranging from businessmen to friends and family. It'll inspect your vocabulary carefully and suggest the best word to make sure you don't have to analyze your writing too much. Grammarly will guide to find the correct one.

In grammarly give us advantages in writing, but the most advantages in grammarly is Grammar Checker which there are two type in grammarly what used for checker our grammar:

1. Red underlines mean that Grammarly has spotted a mistake in your writing. You'll see one if you misspell something. (See what we did there?) You'll also see an underline if you misuse a punctuation mark. If you're worried about typos or grammatical errors that could affect your credibility, Grammarly will help you fix those too. Click any of Grammarly's suggested corrections to apply them to your text, or open a brief explanation to learn more about the error and how to fix it.

2. Blue underlines indicate that Grammarly has spotted an unnecessarily wordy sentence. Grammarly scores each text based on how clear it will be to your readers and guides you to revise it effortlessly. After all, some sentences are grammatically correct but still awkward and hard to follow. Sometimes you can improve a sentence by eliminating unnecessary words. Brilliant sentences are clear and concise.

Grammarly will give feedback on your writing. You will able to catch all kinds of additional issues. For example, fragments and classical word-choice mistakes. You will see suggestions that make your writing sound more confident, polite, and engaging. You will even get vocabulary enhancements for bland or overused words.

\section{METHOD}

This research design is Action research method. The subject of this research was XI IPA class which consist of 32 students. The procedure of collecting data is test (pretest and posttest). The result of the data collecting was describe by the writer. In process of finding data and process collecting data, the researcher describing the result of the pretest and posttest to get know the students' improvement in writing skills. They were instructed to write a phenomenon in daily activity. The research consisted of two cycles. First cycles was given without help from the 
teacher this cycle also used to pretest for students, and the second is given the instruction use the grammarly application to get to know what their improvement.

\section{RESULTS AND DISCUSSION}

\section{Results}

The use of Grammarly application help the students improve their writing skills and checker and also find out the way to fixed the mistake in spelling, grammar and punctuation errors, and enhances vocabulary usage based on the observation and treatment to students.

Result of Research

1. Action and Observation Cycle 1

Firstly, teacher given the material about explanation text. Start from purpose of the text generic structure and language feature and also given the example of the explanation text related the daily activity in social and their environment. After explained the material, students were given the instructed to write a text about phenomenon of daily activity in their environment based their own word. This section give the students free writing to improve and express their idea and also was followed by discussion between teacher and students about what they would have written. This section students able to express their idea at their own written text.

2. Action and observation Cycle 2

In this section, students have produced their own written text. The teacher looked their written text and they were informed about their errors use Grammarly. Students asked to open the Grammarly application in their own gadget. Students move their written text in the Grammarly, than Grammarly show their errors and give the option to choose the correct one and finally students get to know what their mistake. The result of their written text showed that their mistake in writing are reduced without reducing their activity in expressing their idea.

The participant who were instructed to write exposition essay about natural or social phenomenon in their own word in daily life in their own environment with a minimum 150 word in 45 minutes. The exposition used in this research because this genre of text the material learned in previous meeting at the class.

After collecting students' essay, the researcher analyzed the essay to found error using some steps, there are identifying, explaining and evaluating the errors. After categorizing all errors the researcher the data was categorized arranged table to show total errors and percentage of each error. The data show the errors found in the essay before and after use the Grammarly application.

Based on Brown (2007:262),Corder (1991:36-37) and Ellis (1997:18) stated in Faisal (2017), Number of errors based on surface strategy taxonomy of errors before using Grammarly.

The total error results from the table were taken from one of the students who got the most errors.

\begin{tabular}{lcc}
\hline Type of Error & Number of Errors & Percentage of Occurrence \\
\hline Mis-selection & 23 & $65 \%$ \\
\hline Omision & 5 & $15 \%$ \\
\hline Addition & 4 & $10 \%$ \\
\hline
\end{tabular}




\begin{tabular}{lcc}
\hline Misordering & $\mathbf{4}$ & $\mathbf{1 0 \%}$ \\
\hline Total Errors & 36 & $100 \%$ \\
\hline
\end{tabular}

Number of errors based on surface strategy taxonomy of errors after using Grammarly.

\begin{tabular}{lcc}
\hline Type of Error & Number of Errors & Percentage of Occurrence \\
\hline Mis-selection & $\mathbf{3}$ & $\mathbf{8 \%}$ \\
\hline Omision & $\mathbf{2}$ & $\mathbf{3 \%}$ \\
\hline Addition & $\mathbf{1}$ & $\mathbf{2 \%}$ \\
\hline Misordering & $\mathbf{2 \%}$ \\
\hline Total Errors & $\mathbf{7}$ & $\mathbf{1 5 \%}$ \\
\hline
\end{tabular}

\section{Discussion}

The most common type errors in the surface strategy taxonomy found in this study was misselection. They were usually concerned with the rule of word formation which are abundant in English and thus require a lot of effort to learn. Below are some example of mis-selection errors produced by the students. This review section what the researcher found during teaching writing using Grammarly application. The first time the students found it difficulties to start exploring their ideas, then the researcher given the instruction to explore their ide based on daily life in their environment and start to simple thing and the result of their written form there was errors. After implementing to use Grammarly application, the students able to fixed their errors throught Grammarly and found the correct one. Based on that tables as we know that students experienced some increase in writing errors. The result in pre-test if the first activity without an application is found 100 percent or around errors in 36 words showed that the common errors there were $65 \%$ in mis-selection, $15 \%$ in omission, $10 \%$ in addition and $10 \%$ in misordering. The result of post-test showed progress with a reduction in the total errors of $8 \%$ in misselection $3 \%$ in omission $2 \%$ in addition $2 \%$ in misordering total of errors 7 words this result was showed by using the application Grammarly only around $15 \%$ from previous error.

\section{CONCLUSION}

Based on finding and discussion in previous section, the researcher found during implement the research in writing using Grammarly application. First the students the researcher found that had difficult in writing because they still have difficulty in expressing and exploring their ideas in writing. Grounded things because they are afraid of making mistakes, but researchers instruct them to freely explore their ideas through the simple things that are around them in daily life. Secondly after they make the writing form and are guided to find errors in their writing using grammarly, than grammarly application showed the number of errors and why they are used incorrectly and gives recommendations and suggestions for fixing them and a description of their use. The researcher give the suggestion that students should be confident in conveying their ideas into written form as well as maximizing this Grammarly application to help them find errors in writing, so they can find the correct one. It is recommended that teachers give more serious attention errors of students in writing because of solving..

\section{ACKNOWLEDGMENTS}

Alhamdulilahi rabbil'alamin all gratitude to Allah S.W.T who always gave His blessing to the researchers, because of His help the researchers can finish this article completely. The 
researchers would like to say thank you to all the people who always gave their support, motivation and advice to the researchers when conducting this article.

\section{REFERENCES}

Gardner, E. S. (2016). No 主観的健康感を中心とした在宅高齢者における 健康関連指標 に関する共分散構造分析Title. 12(September), 1939.

Iftanti, E. (2016). Improving Students' Writing Skills Through Writing Journal Articles. In Jurnal Bahasa Lingua Scientia (Vol. 8, Issue 1). https://doi.org/10.21274/1s.2016.8.1.1-22

Inez E.A \& C. Nur. (2018). The Implementation of Mind Mapping Technique to Teach Descriptive Text Writing at SMAN 15 Surabaya. 06(2005), 17-24.

Kareviati, E., Yugafiati, R., \& Resmini, S. (2019). Need Analysis of English Department Students As The Basic of Material Development Of Writing For General Communication. ELTIN JOURNAL, Journal of English Language Teaching in Indonesia, 8(1), 1-9.

Mustafa, F., Kirana, M., \& Bahri Ys, S. (2016). Errors in EFL writing by junior high students in Indonesia. International Journal of Research Studies in Language Learning, 5(5). https://doi.org/10.5861/ijrsll.2016.1366

Parmawati, A., Santoso, I., \& Yana, Y. (2020). Improving Students'writing Skill Through Round Table Technique. ELTIN JOURNAL, Journal of English Language Teaching in Indonesia, 8(2), 103-111. https://doi.org/10.22460/eltin.v8i2.p103-111

Pratiwi, K. D. (2015). Students' Difficulties in Writing English ( A Study at The Third Semester Students of English Education Program At University of Bengkulu Academic Year 2011-2012 ) Kristy dwi pratiwi Universitas bengkulu Email: kriskitty2015@gmail.com ABSTRACT The title. Universitas Bengkulu, 1964.

Rizky, R. (2018). Improving Students'writing Skill in Descriptive Text Through Bits and Pieces Game at The Grade VIII 6 of SMPN 1 Tambusai. English Language Teaching and Research, 2(1).

Ruhama, U., \& Purwaningsih, D. I. (2019). Improving Students' Writing Skills through the Application of Synectic Model of Teaching Using Audiovisual Media. English Language Teaching Educational Journal, 1(3), 176. https://doi.org/10.12928/eltej.v1i3.293 